\title{
Gene pool assessment in terms of apple tree generative organs resistance of different ploidy to spring frost
}

\author{
Nina Krasova ${ }^{l, *}$, Zoy Ozherelieva ${ }^{l}$, Anna Galasheva ${ }^{l}$, Olga Panfilova $^{l}$ and Mikhail Tsoy ${ }^{l}$ \\ ${ }^{1}$ Russian Research Institute of Fruit Crop Breeding (VNIISPK), Zhilina, Orel district, Orel region, \\ Russian Federation
}

\begin{abstract}
The results of resistance studies of apple varieties (Malus domestica L.) generative sphere to low temperatures during flowering are presented. The research was carried out on the basis of areas of primary and industrial study of apple varieties and laboratory of physiology of stability of fruit crops of Russian Research Institute of Fruit Crop Breeding in the period 2009-2020. The resistance of the generative organs of the apple tree to spring frost was determined by the method of frost modeling from $-1.0^{\circ} \mathrm{C}$ to $-6.0^{\circ} \mathrm{C}$. The purpose of the research is to establish a critical temperature to identify the stability of the generative sphere to frosts during flowering, to identify the reaction of different ploidiness varieties to low temperatures in flowering time and identify resistant ones. As a result of frost modes modeling, the critical temperature for flower elements $\left(-3.5^{\circ}\right.$ C) was established, and apple varieties resistant to critical temperature were allocated. When using the non-parametric Mann - Whitney criterion, in different phases of flowering reliable (at the value level $p=$ 0.05 ) differences in the genotypes resistance of different ploidy to the simulated spring frosts were identified. Weak stability of the generative sphere in studied triploid (3n) varietal specimens in comparison with diploid $(2 n)$ has been established. Critical temperature was taken by diploid varietal specimens with less damage to flowers and buds $(11.3 \%$ in Antonovka obyknovennaya to $55.3 \%$ in Imant) than triploid (from $61.0 \%$ in ELS 30-30-114 to 100\% Rozhdestvenskoye). Varieties Bolotovskoe, Imrus, Veteran, Kulikovskoe, Orlik with resistance of the generative sphere to frost are recommended for intensive plantings.
\end{abstract}

\section{Introduction}

The success of apple trees (Malus domestica L.) cultivation depends to a large extent on the conformity of the varieties requirements with the soil and climatic conditions of the locality. There are no universal varieties suitable for various gardening zones. For the middle zone of horticulture in Russia, the main limiting factors of high-quality varieties cultivation of apple trees are unfavorable factors of autumn-winter period, lack of heat in summer and possible frosts during the flowering period.

,Corresponding author: krasovang@,vniispk.ru 
The date of the last possible frost in the air in the middle zone of horticulture ranges from May 28-29 in the Oryol and Kursk region to June 4-5 - in the Voronezh, Lipetsk, Tambov region.

The degree of danger depends to a large extent on the timing of onset, intensity, duration of frost, air humidity, varietal features, state and phase of plant development and generative spheres [1-5].

Sharp temperature fluctuations and early warming contribute to the activation of growth processes and resistance reduction of tissues and organs of the tree, loss of frost-resistance condition by flower knops [6-8]. The stability of developing flower knops and buds depends heavily on environmental conditions. It was found that in cool weather, slowdeveloping flower knops are more resistant to low temperatures than fast-developing knops [9].

In the Oryol region, significant damage to flowers by spring frosts was noted in 1994, 1999, 2000, 2004, 2007 and 2017. In 1999, early flowering varieties of summer ripening were significantly affected by frosts at $-3.5{ }^{\circ} \mathrm{C}$ in early May — up to $95-100 \%$ exposed flowers of varieties Orlovim, Bordovoe were damaged. In varieties with a later initial blossom, only single open flowers were damaged, which did not affect the yield [10]. In 2000 and 2004, the minimum air temperature in May fell to $-1.0-3.0{ }^{\circ} \mathrm{C}$ under the associated adverse conditions - low relative humidity (up to 23\%), which prevented normal bee forage. The yield in such conditions was practically absent [11]. In 2017, in mid-May during the flowering period extreme weather conditions developed: on May 11 and 13 the air temperature decreased to $-2^{\circ} \mathrm{C}$ and on the soil surface to $-3.7^{\circ} \mathrm{C}$ with strong northern and northeast wind. Various degrees of damage to the pistil of the open flowers and weak pollination in the absence of bee forage were noted, negatively affecting the yield. Favorable during the flowering period were conditions in 2016 and 2018 with the sum of active temperatures of 315 for 2016 and $343^{\circ} \mathrm{C}-2018$ for the date of flowering. Long, lingering, cool spring with the sum of active temperatures above $+5^{\circ} \mathrm{C}$ and, in this regard, stretched apple flowering period are noted in 2020.

Damage to the generative sphere of apple varieties by spring frosts were noted in Belarus [12], in Tambov region [13, 14], as well as in foreign countries $[5,8,15,16]$.

High stability of the generative sphere is noted in studied forms Malus baccata 1/1, M. prunifolia 23173, Yakutskaya 1, Nizhegorodskaya 2 [17].

Due to the significant loss of crops from frosts during flowering, it is necessary to identify potential and isolate sustainable varieties.

The purpose of the research is to identify the reaction of apple varieties of different ploidy to low temperatures during flowering and the damage of flower elements in different stages of their development by the method of flowers and buds freezing in artificial freezing modeling and isolation of resistant varieties.

\section{Materials and Methods of Research}

The research was carried out on the areas of primary and industrial study of apple varieties and in the laboratory of physiology of stability of fruit crops of Russia Research Institute of Fruit Crops Breeding in the period $2009-2020$.

The research material was the flowering varieties branches, elite seedlings of apple tree of institute breeding and other scientific institutions.

In the first phase (2009-2013), 51 varieties of apple trees were studied with Antonovka obyknovennaya as control.

In the period from 2016 to 2020, varieties samples of apple trees of different ploidy diploids (2n) and triploids (3n) (table 1) were included in the studies. 
Table 1. Genetic origin of apple varieties

\begin{tabular}{|c|c|}
\hline Variety samples & Origin \\
\hline \multicolumn{2}{|r|}{ Diploids (2n) } \\
\hline Antonovka obyknovennaya & Russian selection \\
\hline Elena & Ranneye sladkoye $\times$ Diskaveri \\
\hline Imant & Antey $\times$ Liberti \\
\hline Pamyat' Kovalenko & Belorusskoye malinovoye $\times$ BM 41-497 \\
\hline ELS 31-15-126 & 23-16-96 (seedling .814 open pollination) $\times$ Gulliver \\
\hline $31-35-58$ & Yubiley Moskvy $\times$ Krasa Sverdlovska \\
\hline ELS 32-6-37 & Kornel red $\times$ Svezhest' \\
\hline $18-64-52$ & 814 -open pollination \\
\hline \multicolumn{2}{|r|}{ Triploids $(3 \mathrm{n})$} \\
\hline Akademik Savel'yev & Venyaminovskoe $\times 25-35-144($ Whelsi $4 n \times$ Transporent $4 n)$ \\
\hline ELS 26-44-94 & 11-24-28 (seedling of Golden Graims variety) $\times$ Whelsi $4 n$ \\
\hline ELS 31-2-48 & Afrodita $\times 13-6-106$ (Suvorovtsa seedling) \\
\hline $31-2-102$ & Afrodita $\times 13-6-106$ (Suvorovtsa seedling) \\
\hline ELS 31-2-15 & Afrodita $\times 13-6-106$ (Suvorovtsa seedling) \\
\hline ELS 30-30-30-114 & 23-20-74 (814 - open pollination $\times$ Jaent spay $)$ \\
\hline $30-32-88$ & Prima $\times$ Jaent spay \\
\hline
\end{tabular}

ELS - elite seedling

Resistance of the generative organs of the apple tree to spring frosts was determined by the method of artificial freezing in the climate chamber "Espec" PSL-2KPH (Japan) during temperature modeling $-+1.0^{\circ} \mathrm{C},-2.0^{\circ} \mathrm{C},-3.5^{\circ} \mathrm{C},-5.0^{\circ} \mathrm{C}$ and $-6.0^{\circ} \mathrm{C}[14]$.

Freezing exposition - 3 hours. Branches with inflorescences (at least 100 flowers and buds) were frozen in three repetitions. The base of the branches was processed with graft seal and wrapped in damp cloth. Branches defrosting was carried out at a temperature of $0 \ldots$ $+2^{\circ} \mathrm{C}$, then gradually brought to room temperature at a speed of $1.0{ }^{\circ} \mathrm{C}$ per hour. In each inflorescence, flowers and buds were viewed separately and pistil damage assessed. As a result of freezing modes modeling taking into account the critical temperature of $-3.5{ }^{\circ} \mathrm{C}$, the studied varietal samples were distributed into the groups of generative organs resistance during flowering in according to average damage to buds and flowers [18]:

1. Highly resistant varieties (damaged buds, flowers below $10 \%$ );

2. Resistant varieties (no more than $25 \%$ of buds and flowers damaged);

3. Medium resistant (25.1-50\% of buds and flowers damaged);

4. Weakly resistant (damage to buds, flowers $50.1-75 \%$ );

5. Non-resistant (more than $75 \%$ of buds and flowers damaged).

Statistical processing of the results was performed by the method of dispersion analysis (ANOVA) [19], to compare the degree of generative organs damage of different opening degrees (flowers, buds) of different ploidies varieties groups we used the non-parametric Mann - Whitney U-criterion [20, 21] using the MS Excel 2010 program. The value of the Mann - Whitney U-criterion was determined by the formula

$$
\mathrm{U} \exp =n_{1} \cdot n_{2}+\frac{n_{x}\left(n_{x}+1\right)}{2}-T_{x}
$$

$\mathrm{n}_{1}$ - the number of elements of the first sample; 
$\mathrm{n}_{2}$ - the number of elements of the second sample;

$\mathrm{T}_{\mathrm{x}}$ - greater of the two rank sums

\section{Results and discussions}

\subsection{Evaluation of apple varieties by stability of generative organs. Selection of freeze mode}

The stability of the apple tree generative organs is largely dependent on the phase of their development and varietal features. Crops losses from spring frosts of different varieties can be up to $50-100 \%$ of the crop.

According to a number of researchers, damage to the elements of the flower depends on the degree of its opening: in buds, pistils are most sensitive to low temperatures. Critical at slow opening of the flower in cold weather was temperature from $-3.9^{\circ} \mathrm{C}$ [22] to $-3--5^{\circ} \mathrm{C}$ [23]. According to other data, the limit of negative temperatures that pose a danger to closed, already pigmented apple tree buds is the air temperature $-2.8^{\circ} \mathrm{C}--3.9^{\circ} \mathrm{C}$, for open flowers $-1.7{ }^{\circ} \mathrm{C}--2.2^{\circ} \mathrm{C}[24,25]$, according to other data $--4.2^{\circ} \mathrm{C}--5.3^{\circ} \mathrm{C}$ for pigmented buds and $-2.8^{\circ} \mathrm{C}$ to $-3.9^{\circ} \mathrm{C}$ at the end of flowering [15].

Earlier studies on the resistance of generative organs in 51 varieties of apple trees to spring frost by modelling damaging factors (2009, 2010, 2012 and 2013) showed significant differences in reaction to the freezing temperature from $-2.0^{\circ} \mathrm{C}$ to $-6^{\circ} \mathrm{C}$ depending on the variety and phase of flower development $[10,11]$. At $-2.0^{\circ} \mathrm{C}$ the damage of pistils in open flowers and buds differed significantly in varieties (no lesion - Pervinka, Pamyat' Khitrovo, Orlinka up to $58-90 \%$, and $3 n-$ Sinap orlovskiy, Pamyat' Semakinu). When the freezing temperature was lowered to $-3.5^{\circ} \mathrm{C}$, the damage increased, significantly varying in grades and from the control Antonovka obyknovennaya $\left(\mathrm{F}_{\mathrm{f}}>\mathrm{F}_{\mathrm{t}}\right)$. Slight damage (up to $25 \%$ ) was seen in flowers and buds of varieties Vita, Delikates, Zhelannoye, Zaryanka, Kandil' orlovskiy, Kulikovskoye, Orlik, Transporent.

Further reduction of the freezing temperature to $-5.0^{\circ} \mathrm{C}$ and $-6.0^{\circ} \mathrm{C}$ proved to be detrimental for pistils in open flowers and buds of most varieties (damage 90-100\%) as well as control Antonovka Obyknovennaya with insignificant differences $\left(\mathrm{F}_{\mathrm{f}}<\mathrm{F}_{\mathrm{t}}\right)$.

Therefore, the freezing temperature $-3.5{ }^{\circ} \mathrm{C}$ can be considered critical, because further lowering of the temperature increases the damage and smoothest differences in varieties (Figure 1).

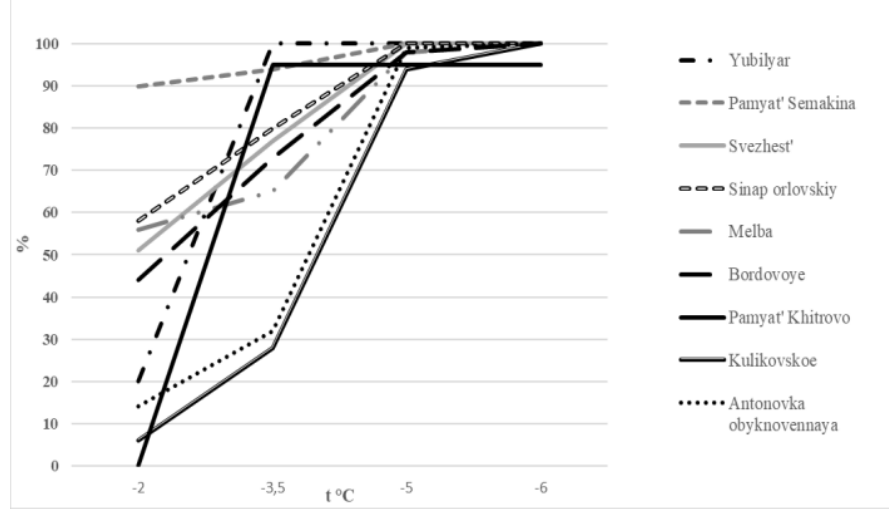

Fig. 1. Degree of damage to apple tree flowers (2009-2010), \% 
Artificial freezing of flowering branches in 2012 and 2013 confirmed the correctness of critical temperature selection to detect the resistance of generative organs of apple varieties to spring freezes (Figure 2).

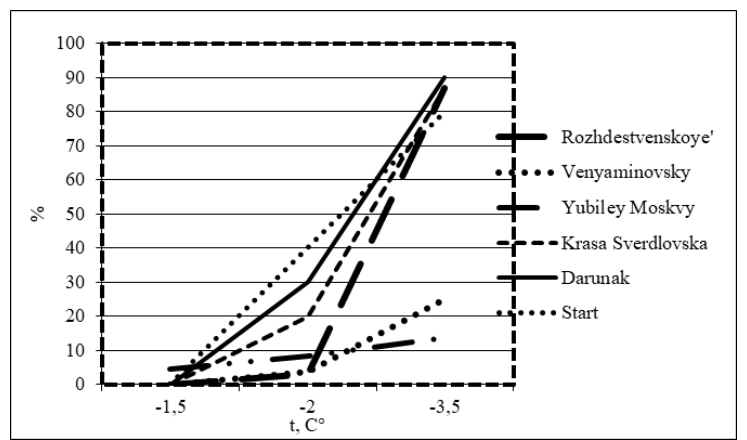

Fig. 2. Damage to apple flower varieties (\%), 2012

Freezing of flowers and buds in different phases of development allowed to identify 11 varieties of resistant (high resistant varieties not identified), 15 - medium resistant, 11 weak and 14 - not resistant $[26,27)$.

From the studied foreign diploid (2n) varieties of apple trees were identified: Delikates with flowers resistant to low temperatures, Priam and Whelsi varieties — with mediumresistant, Melba, Fridom - with low-resistant and Liberti, Red free — with non-resistant flowers.

\subsection{Identification of varieties reaction of different ploidy to low temperatures during flowering}

There are reports of weak flowers resistance of triploid apple varieties [28]. In 2009 2013 studies, these data were confirmed: the triploid apple varieties included in the study showed weak flowers resistance (Darena, Nizkorosloye, Pamyat' Semakinu, Rozhdestvenskoye, Sinap orlovskiy, Yubilyar) with damage to open flowers at -3.5 of 93 $100 \%$. Among $2 \mathrm{n}$, we have identified varieties with different resistance of generative organs, including resistant flower elements to critical temperatures at Antonovka obyknovennaya level and non-resistant, with damage over $75 \%$ of flowers - Belorusskoye sladkoye, Darunak, Krasa Sverdlovska, Liberti, Nadzeyny, Pamyati Khitrovo, Redfri, Start.

In 2016, 2018, and 2020, studies were conducted on the resistance of generative organs in a wider set of $3 n$ varietals compared to $2 n$ varieties of the same age growing at the same site.

Artificial freezing of the apple tree flowering branches in 2016, 2018 and 2020 showed that when exposed to a temperature of $-1.5^{\circ} \mathrm{C}$, the pistils in the open flowers were slightly damaged, in the bud phase remained intact in most varieties. When exposed to temperature $-2.0^{\circ} \mathrm{C}$, the damage to pistils in the open flowers and buds was weak. Statistical analysis showed immaterial differences in damage to flowers and buds by grade at freezing temperatures $-1.0^{\circ} \mathrm{C}$ and $-2.0^{\circ} \mathrm{C}\left(\mathrm{F}_{\mathrm{f}}<\mathrm{F}_{\mathrm{t}}\right)$ at the level of statistical significance $\mathrm{p}=0.05$.

Modeling of freezing $-3.5{ }^{\circ} \mathrm{C}$ showed increased damage to pistils in open flowers and buds with significant differences $\left(F_{f}>F_{t}\right)$ (Table 2, figure 3, 4). 
Table 2. Lesion of flowers and buds apple at a temperature $-3.5^{\circ} \mathrm{C}$ (mean 2016, 2018, 2020)

\begin{tabular}{|l|c|c|c|}
\hline \multirow{2}{*}{\multicolumn{1}{|c|}{ Varieties }} & \multicolumn{3}{|c|}{ Damage to generative organs, \% } \\
\cline { 2 - 4 } & \multicolumn{3}{|c|}{ Diploid varieties } \\
\hline $\begin{array}{l}\text { Antonovka } \\
\text { obyknovennaya }\end{array}$ & $17.7 \pm 3.4$ & $4.8 \pm 4.8$ & $11.3 \pm 3.4$ \\
\hline Imant & $79.8 \pm 10.7$ & $40.0 \pm 15.8$ & $59.9 \pm 11.5$ \\
\hline Pamyat' Kovalenko & $65.5 \pm 19.1$ & $9.1 \pm 6.1$ & $37.3 \pm 10.7$ \\
\hline 18-64-52 & $67.7 \pm 16.6$ & $32.8 \pm 10.6$ & $50.3 \pm 13.4$ \\
\hline ELS 31-15-126 & $47.6 \pm 22.0$ & $14.2 \pm 9.8$ & $30.9 \pm 15.2$ \\
\hline 31-35-58 & $60.4 \pm 19.5$ & $23.2 \pm 14.4$ & $41.9 \pm 11.5$ \\
\hline ELS 32-6-37 & $42.8 \pm 13.7$ & $21.6 \pm 5.7$ & $32.2 \pm 9.7$ \\
\hline Elena & $59.9 \pm 19.8$ & $28.9 \pm 9.0$ & $44.4 \pm 10.9$ \\
\hline Average & 55.2 & 20.2 & 38.5 \\
\hline & \multicolumn{3}{|c|}{ Triploid varieties } \\
\hline ELS 29-44-94 & $83.3 \pm 8.3$ & $41.3 \pm 9.5$ & $62.3 \pm 3.5$ \\
\hline ELS 31-2-15 & $88.7 \pm 1.1$ & $58.6 \pm 11.3$ & $68.1 \pm 5.2$ \\
\hline ELS 31-2-48 & $86.9 \pm 10.1$ & $72.2 \pm 14.9$ & $81.2 \pm 8.7$ \\
\hline ELS 31-2-102 & $99.1 \pm 0.6$ & $77.9 \pm 19.1$ & $88.5 \pm 9.5$ \\
\hline ELS 30-30-30-114 & $80.7 \pm 3.4$ & $41.3 \pm 4.0$ & $61.0 \pm 2.3$ \\
\hline 30-32-88 & $92.8 \pm 4.2$ & $64.3 \pm 21.8$ & $78.5 \pm 13.0$ \\
\hline Akademik Savel'ev & $88.8 \pm 1.2$ & $56.2 \pm 17.5$ & $72.5 \pm 9.3$ \\
\hline Average & 88.6 & 57.2 & 72.9 \\
\hline & \multicolumn{2}{|c|}{$\mathrm{F}_{\mathrm{f}}>\mathrm{F}_{\mathrm{t}}$ at $\mathrm{p}=0.05$} & \\
\hline
\end{tabular}

Note: Statistical analysis showed immateriality of differences in damage to flowers and buds by varieties at freezing temperatures of minus $1.0^{\circ} \mathrm{C}$ and minus $2.0^{\circ} \mathrm{C}(\mathrm{Ff}<\mathrm{Ft})$. At $-3.5^{\circ} \mathrm{C}$ differences are significant $(\mathrm{Ff}>\mathrm{Ft})$ at the level of statistical significance $\mathrm{p}=0.05$.

ELS -Elite seedling

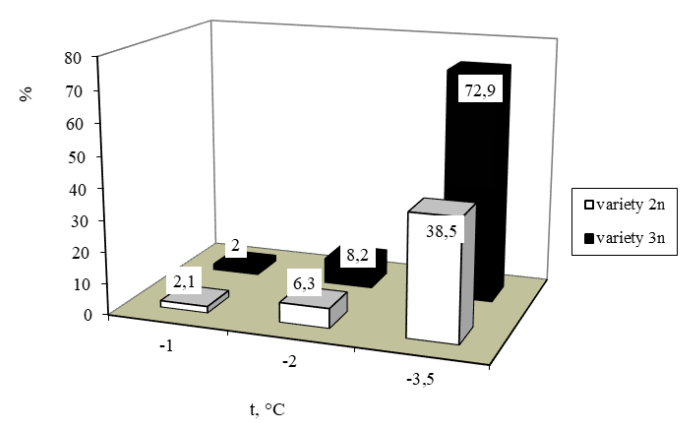

Fig. 3. The degree of damage to the generative organs of the apple tree during artificial freezing, \% (average for 2016, 2018, 2020 for groups $2 n$ and $3 n$ ).

Significance of differences at the freezing temperature $-3.5^{\circ} \mathrm{C}$ between a group of varieties with a $2 \mathrm{n}$ chromosomes set and a group of varieties $-3 \mathrm{n}$ is confirmed by the Mann - Whitney U-criterion at level of statistical significance $p=0.05$. Damage of open 
flowers in group $2 \mathrm{n}$ averaged to $55.2 \%$, pistils $-20.2 \%$ and in group $3 \mathrm{n}-88.6$ and $57.2 \%$ respectively.

Critical temperature $-3.5{ }^{\circ} \mathrm{C}$ on average for flowers and buds of diploid varieties suffered less damage (from 11.3\% in Antonovka Obyknovennaya to 59.9\% in Imant variety than triploid (from 61.0\% for ELS 30-30-114 to 88.5\% ELS 31-2-102) (Table 2)

At the same time, varieties in the diploid group vary significantly in the damage of flower elements - from $17.7 \%$ in Antonovka obyknovennaya to $79.8 \%$ in Imant variety and by buds - from 4.8\% in Antonovka obyknovennaya to $32.8 \%$ - in 18-64-52. According to average indicators, varietal samples with $2 \mathrm{n}$ chromosomes are distributed as follows: resistant group - Antonovka obyknovennaya (damaged flowers and buds $11.3 \%$ ), medium resistant - Pamyat' Kovalenko, ELS 31-15-126, ELS 32-6-37, 31-35-58, Elena $(30.9-44.4 \%)$ and weakly resistant - 18-64-52 and Imant (50.3 - 59.9\%) (Figure 5).

In all studied $3 \mathrm{n}$ varieties, the damage was significantly stronger: flowers were damaged from $80.7 \%$ to $99.1 \%$, buds were damaged from 41 to $77.9 \%$. On average in 3 years, no medium resistant and resistant samples were identified in the group of $3 \mathrm{n}$ varietal samples studied.

3n varieties Akademik Savel'ev and ELS 26-44-94. 30-30-114. 31-2-15 and selected seedling 30-32-88 showed weak resistance (damage to the flower elements averaged 61.0 - 72.5\%); not resistant to critical freezing temperature during flowering with damage to pistils in buds and open flowers were elite seedlings 30-32-88, 31-2-48, 31-2-102 (78.5 $88.5 \%$ ) (Figure 4, 5).

Thus, a large diversity in the resistance degree of the generative sphere in the modeling of frosts during flowering in $2 \mathrm{n}$ varieties (from resistant to non-resistant) and a weaker resistance of the generative sphere in studied $3 \mathrm{n}$ apple varieties, in the group of which there was no resistant and medium-resistant variety specimen.

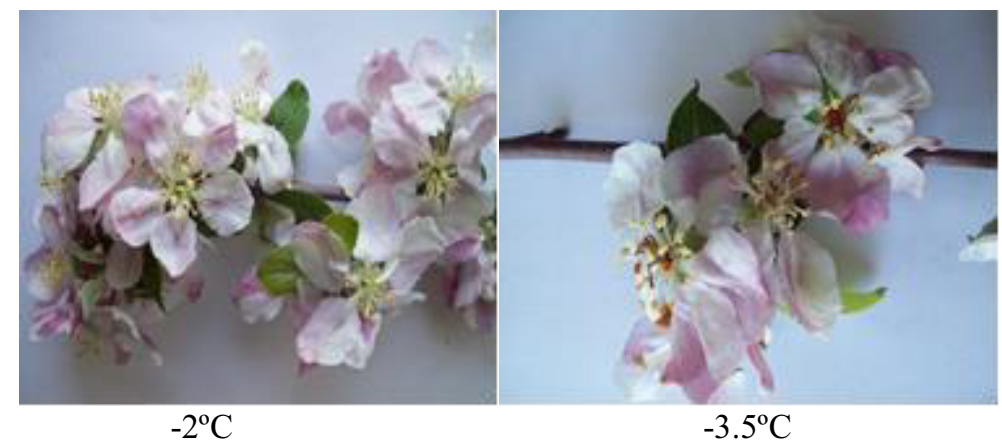

Fig. 4. Damage of hybrid form flowers 30-32-88 (3n) after artificial freezing, 2020

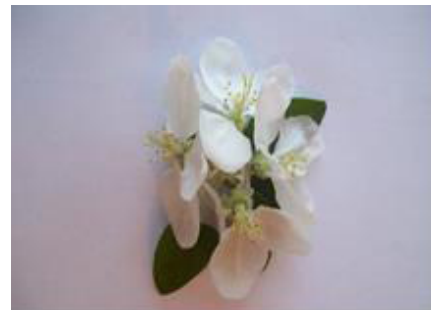

Antonovki obyknovennoy (2n)

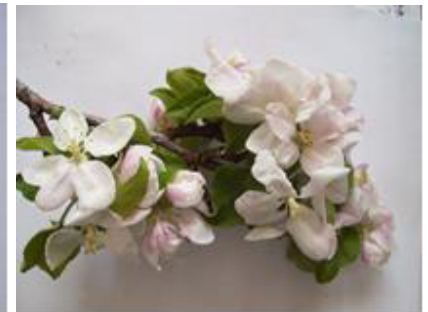

$31-15-126(2 n)$

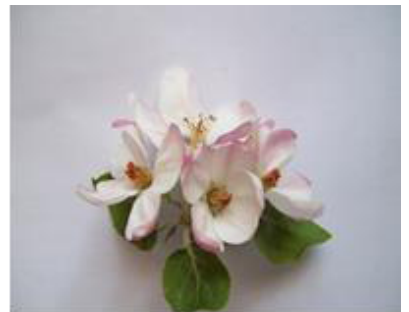

Akademik Savel'ev (3n)

Fig. 5. Damage of diploid and triploid varieties of apple trees at $-3.5^{\circ} \mathrm{C}(2020)$ 


\section{Conclusions}

As a result of the freezing modes modeling of flowers in different development phases, a critical temperature of $-3.5{ }^{\circ} \mathrm{C}$ has been established to detect resistance of generative organs to spring frosts. Based on the analysis of the freezing data, a reliable difference in the varieties stability of different ploidiness is shown.

As a result of freezing modes modeling taking into account the critical temperature of $3.5{ }^{\circ} \mathrm{C}$, the studied varietal samples were distributed into the groups of generative organs resistance during flowering in according to average damage to buds and flowers [18]:

1. Highly resistant varieties (buds, flowers damage below 10\%) - not detected;

2. Resistant varieties (no more than $25 \%$ of buds and flowers damaged) - Antonovka obyknovennaya, Vita, Delikates, Zhelannoye, Zaryanka, Zdorov'ye, Kandil' orlovskiy, Kulikovskoye, Papirovka - all 2n;

3. Medium-resistant (damaged buds and flowers 25.1-50.0\%) - Bolotovskoye, Veteran, Imrus, Yelena, Orlovskoye polosatoye, Orlik, Orlovim, Pamyat' voinu, Pamyat' Kovalenko, Pepin shafrannyy, Pervinka, Priam, Prishvinskoye, Radost' Nadezhdy, Ranneye aloye, Uelsi, ELS 32-6-37, 31-35-58 and 31-15-126 - all 2n;

4. Weakly resistant (bud, flower damage 50.1-75.0\%) 2n - Bordovoye, Brusnichnoye, Ven'yaminovskoye, Imant, Melba, Orlinka, Pervinka, Svezhest', Yubiley Moskvy, Fridom, selected seedlings 18-64- 52. and 3n - Akademik Savel'ev, Nizkorosloye, Sinap orlovskiy, ELS 26-44-94, ELS 30-30-30-114, ELS 31-2-15;

5. Non-resistant (more than $75 \%$ buds and flowers damaged) $2 \mathrm{n}$ - Belorusskoye sladkoye, Darunak, Krasa Sverdlovska, Liberti, Nadzeyny, Pamyati Khitrovo, Redfri, Start and 3n - Darona, Nizkorosloye, Pamyat' Semakinu, Rozhdestvenskoye, Yubilyar, ELS 31-2-48, ELS 31-2-102, 30-32-88.

Varieties Bolotovskoe, Imrus, Veteran, Kulikovskoe, Orlik with resistance of the generative sphere to frost are recommended for intensive plantings.

\section{References}

1. L.J. Friesen, S.C. Stushnoff, Hortscience, 20, 744-746 (1985)

2. S. Lu, R.M. Rieger, Hort. Sci., 68, 343-347 (1993)

3. K.B. Perry, Horttechnology, 8, 10-15 (1998)

4. I. Stepulaitiene, A. Zebrauskiene, V. Stanys, Zemdirbuste-Agriculture, 100 (2), 175 178 (2013). doi 10.13080/z-a.2013.100.022

5. M.R. Salazar-Gutiérrez, B. Chaves, G. Hoogenboom, Sci. Hortic. (Amsterdam), 198, 344-35 (2016) doi.org/10.1016/j.scienta.2015.12.003

6. M. Sedgley, Hort. Rev., 12, 223-264 (1990)

7. M. Faust, A. Erez, L.J. Rowland, S.Y. Wang, Hortscience, 32, 623-629 (1997)

8. Y. Vitasse, L. Schneider, L. Schneider, C. Rixen, C. Rixen, M. Rebetez, M. Rebetez, Agric. For. Meteorol., 248, 60-69 (2018) doi.org/10.1016/j.agrformet.2017.09.005.

9. C. Miranda. L.G. Santesteban. J.B. Royo, HortScience, 4 (2), 357-361(2005)

10. N.G. Krasova, Z.E. Ozherelyeva, A.M. Galasheva, N.M. Glazova, Bulletin of agrarian science, 21, 50-53 (2009)

11. N.G. Krasova, A.M. Galasheva, Z.E. Ozherelieva, Breeding and variety culture of fruit and berry crops, 4 (1-2), 66-71 (2017)

12. Z.A. Kozlovskaya, S.A. Yarmolich, G.M. Marudo, Fruit-Growing, 17, 25-29 (2005)

13. V.U. Skripnikov, M.K. Skripnikova, Resistance of apple varieties of the middle zone of the Russian Federation to frost, Main results and prospects of scientific researches of the All-Russia Scientific and Research Institute of Horticulture named after. I.V. Michurina, 31-37 (2001). 
14. V.G. Leonchenko, R.P. Evseeva, E.V. Zhbanova, T.A. Cherenkova, Laboratory assessment of flowers and buds of apple trees resistance to spring frosts, In methodical recommendations Pre-selection of prospective genotypes of fruit plants for ecological resistance and biochemical value of fruits, 21-23 (2007).

15. L. Szalay, Z. György, M. Tóth, Scientia Horticulturae, 253, 309-315 (2019) doi.org/10.1016/j.scienta.2019.04.055

16. M. Farajzadeh, M. Rahimi, G. A. Kamali, T., Meteorological Application, 17, 45-52 (2010) https://doi.org/https://doi.org/10.1002/met.159.

17. N.I. Savelyev, N.N. Savelyeva, A.N. Yushkov, Promising apple varieties immune to scab, 128 (Michurinsk, 2009)

18. S.V. Rezvyakova, E.A. Dolmatov, S.D. Knyazev, Study of the resistance of buds, flowers and ovaries to frost, In the monograph Program and method of variety study of fruit, berry and nut crops, Oryol, All-Russia Scientific and Research Institute for Fruit Crops Selection, 74-76 (1999)

19. B.A. Dospekhov, Field Experiment Methodology, 271 (1973)

20. L.C. Hamilton, Statistics with STATA: Updated for Version 10, USA (2009)

21. Stata: Release 12, Statistical Software, College Station, TX: StataCorp LP, (2011)

22. W.H. Chandler, Fruit Garden (1960).

23. F.D. Likhonos, A.S. Tuz, A.Y. Lobachev, Apple tree. Cultural flora of the USSR, 125 (1983)

24. E.L. Loewel, Dte Frostschaden in der Blute unserer Obstbaume (1950)

25. M.A. Solovyova, Winter resistance of fruit crops under different growing conditions, 238 (Moscow, 1967)

26. N.G. Krasova, Z.E. Ozherelyeva, L.V. Golyshkina, M.A. Makarkina, A.M. Galasheva, Winter resistance of apple varieties, 184 (Oryol, 2014)

27. Z.E. Ozherelieva, N.G. Krasova, A.M. Galasheva, Fruit growing and berry growing in Russia, 58, 226-232 (2019)

28. E. Kemmer, F. Schults, The Problem of Cold-Hardiness of Fruit Trees, 135 (1958) 